УДК 628.513:631.86:576.89:579.62

Корчан Л. М., кандидат ветеринарних наук,

Писаренко П. В. доктор сільськогосподарських наук,

Корчан М. І. кандидат ветеринарних наук

Полтавська державна аграрна академія

\title{
СПОСІБ ЗНЕЗАРАЖЕННЯ ГНОЮ І ОТРИМАННЯ 3 НЬОГО ВИСОКОЯКІСНОГО ДОБРИВА
}

\section{Рецензент - доктор ветеринарних наук С. М. Кулинич}

Мета статmі - створення більш дешевого і ефективного способу знезараження гною тварин, забезпечення скорочення термінів знезараження гною і покращання якості отриманого з нього добрива.

Методика дослідження. В експериментальних дослідженнях закладено дослідні штабелі твердого підстилкового гною великої рогатої худоби і кіз, які пошарово обробляли в різних співвідношеннях до гною йодобромною мінералізованою пластовою водою (далі МПВ) Решетняківського родовища. Контрольні штабелі гною не обробляли МПВ. Через кожні 15 днів після закладання штабелів від них відбиралися проби гною для вивчення процесу його знезараження від бактеріальних і інвазійних збудників.

Результати дослідження. Результати проведених мікробіологічних $і$ гельмінтологічних досліджень показали повне знезараження гною від патогенної мікрофлори, яєць і личинок гельмінтів на 30-45 день у літній $і$ 60-90 день у зимовий період року в дослідних штабелях гною після пошарової обробки його МПВ в об'ємних співвідношеннях $50 \mathrm{r} / \mathrm{M}^{3}$ гною. В контрольних штабелях гній залишався не знезаражений протягом усього періоду спостереження. Було також доведено, що після обробки штабелів гною МПВ відмічається істотне збільшення в ньому органічної речовини і поживних елементів: азоту загального, азоту аміачного фосфору і калію.

Елементи наукової новизни. Запропонований спосіб знезараження гною і отримання з нього високоякісного добрива включає додавання активного компоненту для прискорення процесу біотермічного знезараження гною тварин шляхом пошарової обробки його природнім мінералом - йодобромною мінералізованою пластовою водою.

Практична значущість. Запропонований спосіб знезараження гною і отримання з нього високоякісного добрива є дешевим, ефективним, дозволяс прискорити процес біотермічного знезараження гною тварин, істотно знизити забруднення навколишнього середовища і може бути використаний як засіб підвищення поживності органічних добрив. Значно посилює практичний інтерес до МПВ $i$ той факт, щу запаси цього природного мінералу в Украйні не обмежені.

Ключові слова: гній, біотермічне знезараження, добрива, мінералізовані пластові води.

Корчан Леонід Миколайович - кандидат ветеринарних наук, старший викладач кафедри паразитології та ветеринарно-санітарної експертизи, Полтавська державна аграрна академія, вул. Сковороди, 1/3, м. Полтава, 36003, Україна, e-mail: korchan198@gmail.com, ORCID ID: 0000-0002-6064-5922.

Писаренко Павло Вікторович - доктор сільськогосподарських наук, професор, академік інженерної Академії України, перший проректор, Полтавська державна аграрна академія вул. Сковороди, 1/3, м. Полтава, 36003, Україна, e-mail: pavlo.pysarenko@pdaa.edu.ua, ORCID ID: 0000-0002-4915$265 \mathrm{X}$.

Корчан Микола Іванович - кандидат ветеринарних наук, доцент, доцент кафедри терапії імені П.І. Локеса, Полтавська державна аграрна академія, вул. Сковороди, 1/3, м. Полтава, 36003, Україна, e-mail:korchan198@gmail.com.

Постановка проблеми. Гній - це органічна маса, що складається із екскрементів (фекалії i сеча) тварин та використаної підстилки (солома, опилки, торф і ін.). Наявність органічних речовин робить гній незамінним добривом, яке підвищує родючість грунту та покращує його стру- ктуру. Гній, як цінне добриво, треба зберігати. Проте, варто пам'ятати, що гній - це найбільш небезпечний фактор передачі збудників інфекційних i, особливо, інвазійних хвороб. У твердому гної збудники туберкульозу, бруцельозу, лістеріозу, паратифу, бешихи зберігають свою жит- 


\section{СІЛЬСЬКЕ ГОСПОДАРСТВО. ТВАРИННИЦТВО}

тєдіяльність від 70 до 260 днів, а збудники дерматомікозів - більше восьми місяців. У цьому органічному середовищі яйця і личинки гельмінтів зберігають життєздатність до 12 і більше місяців. Серед збудників інвазійних хвороб особливе значення мають так звані геогельмінти, цикл розвитку яких відбувається без участі проміжного хазяїна. У зв'язку з цим не виключені можливості зараження людей і тварин при внесенні такого гною і фекалій у грунт. Крім цього епідемічна і епізоотична небезпека відходів тваринництва проявляється й у тім, що гній у більшості випадків $€$ місцем розмноження мух і гризунів, які є переносниками багатьох інфекційних та інвазійних захворювань: дизентерії, паратифу, бешихи, лептоспірозу тощо.

Отже, не знезаражений гній має велику загрозу контамінації водоймів, грунту, підгрунтових вод, кормів і пасовищ небезпечними для людей і тварин збудниками. Такі обставини змушують відмовитися від практики вивозу на поля непідготовленого гною і вжити заходів щодо його знезараження і правильного зберігання з метою одержання якісного органічного добрива. Безладне зберігання гною, зваленого в купи, призводить до втрат 50-60\% поживних речовин і забруднення території.

Залежно від технології утримання тварин одержують гній підстилковий (вологість 68$85 \%$ ), напіврідкий (вологість 86-92 \%) і гнойові стоки - гноївка (вологість більше $92 \%$ ) $[5,10,11]$.

Аналіз основних досліджень і публікацій, у яких започатковано розв'язання проблеми. У літературних джерелах висвітлено чимало способів знезараження гною від заразно хворих тварин, які використовуються у ветеринарній практиці $[2,4,13,14]$.

Спалювання гною $є$ найбільш задовільним 3 ветеринарно-санітарної оцінки за обсіменіння його спороутворюючими збудниками.

Знезараження гною хімічними засобами. Цей спосіб знезараження гною застосовується в досить великих масштабах, особливо в господарствах, у яких $\epsilon$ інфекційно хворі сільськогосподарські тварини. Задля цього як хімічні агенти використовуються речовини, які згубно діють на мікроорганізми, а саме хлорне вапно, формалін, рідкий аміак та інші сполуки. Недоліком такого способу знезараження є великі витрати дорогоцінних реагентів, а також при цьому не забезпечується повна дезінвазія гною і його знезараження від патогенної мікрофлори, оскільки формальдегід і аміак мають високу летучість. До того ж такі речовини, як аміак, формальдегід, вапняне молоко - це гостротоксичні, сильнодіючі речовини четвертого класу небезпеки, забруднюють навколишнє середовище, потрапляючи в грунт, можуть знищувати нормальну грунтову мікрофлору.

Механічний спосіб знезараження гною включає різні механічні перетворення гнойових мас: відстоювання, прискорену сепарацію тощо. Основними недоліками механічного способу знезараження гною є облаштування накопичувачів великих розмірів, тривалий строк витримування (6-12 місяців), неповне його знезараження. Адже навіть після 1,5-річної витримки здатні зберігати життєздатність 30-80 \% яєць гельмінтів.

Невеликі об’єми рідкого гною, гнойових стоків й осаду від відстійників знезаражують термічним способом за температури $130{ }^{\circ} \mathrm{C}$, тиску 0,2 МПа і експозиції 10 хвилин за допомогою мобільної установки для термічного знезараження гною.

На великих тваринницьких комплексах рідкий гній поділяють на тверду і рідку фракції шляхом застосування відстійників. Тверду фракцію гною складають у штабелі для біотермічного знезараження, після чого вивозять на поля для приготування компостів. Рідку фракцію зливають в аеротанки для біологічного очищення за рахунок розкладання речовин під впливом кисню повітря та нижчих мікроорганізмів. Освітлену рідину знезаражують хлором. На великих агропромислових комплексах пропонується також метод іонізуючого випромінювання. Однак, впровадження цього методу стримується через необхідність застосування порівняно дорогих джерел випромінювання.

Усі ці відомі і досліджені способи знезараження гною не набули повсюдного впровадження. Це пов'язано, очевидно, з рентабельністю, доступністю, економічною політикою господарювання, більшими матеріальними витратами. Крім того залишається невирішеним питання надійності існуючих методів знезараження гною.

Незважаючи на велику кількість розроблених методів підвищення екологічної безпеки тваринницьких відходів, на сьогодні найпопулярнішим методом знезараження гною є біотермічний метод. Біотермічний метод знезараження гною обгрунтований виникненням у штабелях гною під впливом життєдіяльності термофільних мікроорганізмів високої температури $\left(60-70{ }^{\circ} \mathrm{C}\right)$, яка викликає пагубну дію на збудників інфекційних і інвазійних хвороб тварин. Гній, одержаний від тварин хворих на спороутворюючі форми бакте- 


\section{СІЛЬСЬКЕ ГОСПОДАРСТВО. ТВАРИННИЦТВО}

рій, спалюють.

Для знезараження гною за біотермічним методом на окремому відведеному майданчику не ближче 200 м від тваринницьких приміщень, водойм, криниць і без ухилів до них риють котлован завширшки 3 м і завглибшки $25 \mathrm{~cm}$, довільної довжини. Дно його із заглибиною (жолобом) розміром $50 \times 50$ см на всю довжину по середині утрамбовують шаром глини в 15-20 cм. Перед укладанням гною жолоб покривають жердинами або хмизом, а потім шаром в $25-40$ см соломи чи сухого гною від здорових тварин. Після цього накладають конусом заввишки 1,5-2 м штабель із гною від хворих тварин, залишаючи вільними по 40-50 см краї котлована. Такий штабель покривають 3 усіх боків шаром $10 \mathrm{~cm}$ (взимку 40 см) соломи, торфу або гною від здорових тварин. Поверх нього насипають землю або пісок шаром завтовшки $10 \mathrm{~cm}$.

Розмноження термофільних мікроорганізмів у штабелях гною можливе лише за визначених умов: достатнього надходження повітря у товщу штабеля, а також вологості гною в межах 50$70 \%$. Сухий гній рекомендується змочувати водою. У холодний період року доцільно використовувати для цього теплу воду. Тривалість знезараження гною близько 2-3, взимку 4-6 місяців. Після цього гній використовують для удобрювання полів господарства.

Але досить часто не повністю виконуються вимоги щодо біотермічного знезараження гною, знезараження його проходить тривалий період, в утвореному органічному добриві втрачаються поживні якості. Для підвищення ефективності знезараження гною і подальшого отримання із нього більш якісного органічного добрива намагаються використовувати такі активні компоненти: термофільні мікроорганізми та їх асоціації, що сприяє накопиченню в ньому антибіотичних речовин та прояву більшої антагоністичної активності щодо патогенних мікроорганізмів; солей полівалентних металів $\mathrm{Fe}, \mathrm{Mg}, \mathrm{Mn}, \mathrm{Cu}, \mathrm{Zn}$, які значно прискорюють процес знезараження гною і покращують якості отриманого із нього добрива; рідкого аміаку, який вводять у самі низинні шари штабеля гною, пошарова обробка штабелів гною стічними водами деревообробляючих і мебельних підприємств, що містять знезаражуючий препарат - карбамідоформальдегідну смолу, що також посилює його знезараження $[4,12,14]$.

Проте, технологічний процес цих способів знезараження і приготування з нього органічного добрива відрізняється складністю із застосуванням спеціального обладнання, дорогих активних компонентів, транспортних витрат, що унеможливлює більшою мірою використання їх в умовах сільського господарства. Крім того, такі активні компоненти, як рідкий аміак, формальдегід (складова частина карбамідоформальдегідної смоли) $є$ достатньо токсичними, екологонебезпечними сполуками.

Мета роботи - створення більш дешевого i ефективного способу знезараження гною тварин.

У завдання досліджень входило: розробити спосіб, який забезпечує скорочення термінів знезараження гною і покращання якості отриманого 3 нього добрива.

У зв'язку із кризовим станом сільського господарства в Україні, складними економічними умовами на багатьох агропідприємствах виникає необхідність пошуку нових і недорогих активних компонентів для підвищення ефективності біотермічного знезараження гною і подальшого отримання із нього більш якісного органічного добрива.

У цьому плані, на наш погляд, великі перспективи має застосування мінералізованих пластових вод (далі МПВ), які $є$ супутнім продуктом під час розробки та експлуатації родовищ нафти.

МПВ - це багатокомпонентна фізико-хімічна система, що складається із численних сполук (мінеральних, органічних і газових), які знаходяться в рухливій рівновазі. У МПВ виявлено більше 60 елементів таблиці Д. І. Менделєєва, загальна мінералізація їх складає до 150 г/л. Вміст йоду і брому, як найбільш поширених мікрокомпонентів йодо-бромної МПБ більшості нафтових родовищ України, коливається відповідно в межах 30-70 мг/дм³ і 200-350 мг/дм ${ }^{3}$. За даними Одеського науково-дослідного інституту курортології і медичної реабілітації МПВ не мають біологічно небезпечних сполук, солей важких металів, радіонуклідів i, за висновком інституту екогігієни і токсикології імені Л. І. Медведя MO3 України, малотоксичні для організму тварин [6].

В останні роки МПВ знаходить широке застосування в різних напрямах землеробства, бальнеолікуванні серцево-судинних хвороб, захворювань центральної і периферичної нервової системи, опорно-рухового апарату, захворювань шкіри бактеріальної і грибкової етіології у людей $[3,7,9]$.

\section{Матеріали і методи досліджень.}

В експериментальних дослідженнях закладено дослідні штабелі твердого підстилкового гною великої рогатої худоби і кіз, які пошарово обробляли в різних співвідношеннях до гною 
МПВ Решетняківського родовища. Контрольні штабелі гною не обробляли МПВ.

Через кожні 15 днів після закладання штабелів від них відбиралися проби гною для вивчення процесу його знезараження від бактеріальних i інвазійних збудників. Видову приналежність мікроорганізмів, активність мікробного знезараження гною проводили на підставі мікроскопії мазків, виготовлених із відібраних проб гною; вивченні культуральних і біохімічних властивостей мікроорганізмів і біопроби.

Результативність дезінвазії оцінювали шляхом мікроскопічного дослідження тест-проб. Життєздатність яєць гельмінтів і личинок оцінювали за методикою Г. А. Котельникова [8]. Видову диференціацію гельмінтів здійснювали за визначником «Атлас гельмінтів тварин» [1].

Після чотирьох місяців зберігання гною в штабелях було також проведено вивчення його хімічного складу.

Результати дослідження. Результати проведених мікробіологічних і гельмінтологічних досліджень показали повне знезараження гною від патогенної мікрофлори, яєць і личинок гельмінтів на 30-45 день у літній і 60-90 день у зимовий період року в дослідних штабелях гною після пошарової обробки його МПВ в об'ємних спів-

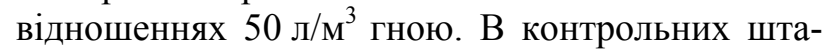
белях гній залишався не знезаражений протягом всього періоду спостереження. У відібраних пробах гною при цьому були виділені такі мікроорганізми: E. coli, S. enteritidis, Str. agalactiae,

\section{БІБЛІОГРАФІЯ}

1. Атлас гельмінтів тварин/ Авт. кол. I. С. Дахно, А. В. Березовський, В. Ф. Галат та ін. Київ : Ветінформ, 2001. 118 с.

2. Дезінфекція гноївки. URL : http://veterinarua.ru/lepizootologiya/2222-dezinfektsiya-gnojivki.html (дата звернення 13.02.2019).

3. Егоров Л. В. Применение йодобромной воды у больных с парадонтитом в условиях курортов. Стоматология. 1990. Т. 69 . № 3. C. 34-35.

4. Ефективність знезаражування гною різних видів сільськогосподарських тварин реагентами хімічної природи / Ю. Ю. Довгій, Д. В. Фещенко, Н. О. Рябцева та ін. Вісник Полтавськой державної аграрної академії. 2013. № 2. C. 92-94.

5. Загальна епізоотологія : підручник / Авт. кол. Б. М. Ярчук, П. І. Вербицький, В. П. Литвин та ін. ; За ред. Б. М. Ярчука, Л. Є. Корнієнка. Бі-
St. albus; яйця трихурисів жуйних тварин, личинки Strongyloides papillosus, личинки кишкових стронгілят ряду Strongylida: Chabertia ovina, Haemonchus contortus, Oesophagostomum radiatum.

У результаті проведених експериментів доведено, що після обробки штабелів гною МПВ відбувається цілий ряд позитивних змін у його якісному складі. При використанні МПВ у дозі 50 $\pi / \mathrm{M}^{3}$ гною після чотирьох місяців його зберігання відмічається істотне збільшення в ньому органічної речовини і поживних елементів: азоту загального, азоту аміачного фосфору і калію у відсотках $(19,4 ; 0,84 ; 0,35 ; 0,59 ; 0,85$ в досліді та 18 ; 0,$60 ; 0,10 ; 0,43 ; 0,72$ в контролі).

На даний спосіб знезараження гною і отримання 3 нього більш якісного добрива отримано деклараційний патент [13].

Висновок. Запропонований спосіб знезараження гною і отримання 3 нього високоякісного добрива є дешевим, ефективним, дозволяє прискорити процес біотермічного знезараження гною тварин шляхом пошарової обробки його йодобромною мінералізованою пластовою водою в об'ємних співвідношеннях 50 л/ $\mathrm{m}^{3}$, істотно знизити забруднення навколишнього середовища і може бути використаний як засіб підвищення поживності органічних добрив. Значно підвищує практичний інтерес до МПВ і той факт, що запаси цього природного мінералу в Україні не обмежені.

ла Церква : Білоцерківський дер. аграрний ун-т, 2002. $656 \mathrm{c}$.

6. Заключительный отчет о научноисследовательской работе Одесского НИИ курортологии и медицинской реабилитации : Изучить пластовые воды нефтяных месторождений на шести участках Полтавской области, определить перспективу лечебного применения и дать лечебную оценку. Одесса, 1991. 20 с.

7. Зорин П. М. Бальнеология кожных больных йодобромной водой Ахтырского источника. Вестник дерматологии и венерологии. 1965. № 11. C.77-80.

8. Котельников Г. А. Диагностика гельминтозов животных. Москва : Колос. 1974. 240 с.

9. Набок М. Ф. Лечение заболеваний периферической нервной системы йодобромными водами Борислава. Врачебное дело. 1965. № 8. C. 121-122. 


\section{СІЛЬСЬКЕ ГОСПОДАРСТВО. ТВАРИННИЦТВО}

10. Паразитолологія та інвазійні хвороби тварин : підручник / Авт. кол. В.Ф.Галат, А. В. Березовський, Н. М. Сорока, М. П. Прус. Київ : Урожай, 2009. С. 21-22.

11. Скрябин К. И. Советская энциклопедия. Москва : «Советская энциклопедия». 1973. Т. 4. C. 323-325.

12. Спосіб знезараження гною 3 подальшим отриманням 3 нього добрива : пат. UA 29772 / 3. М. Шкавро, О. Ф. Омельченко, М. І. Медведев та ін. ; опубл. 15.11.2000.

\section{REFERENCES}

1. Dakhno, I. S., Berezovs'kiy, A. V., Galat, V. F., et al. (2001). Atlas gel'mintiv tvarin [Atlas of animal helminths]. Kyiv: Vetinform [In Ukrainian].

2. Dezinfektsiya gnoïvki [Disinfection of the nipple]. Retrieved from: http://veterinarua.ru/ lepizootologiya/2222-dezinfektsiya-gnojivki.html [In Ukrainian].

3. Egorov, L. V. (1990). Primenenie yodobromnoy vody $\mathrm{u}$ bol'nykh $\mathrm{s}$ paradontitom $\mathrm{v}$ usloviyakh kurortov [Application of iodine-bromine water for patients with paradontitis in the conditions of resorts]. Dentistry, 3, vol. 69. pp. 34-35 [In Russian].

4. Dovgiy, Yu. Yu.,

Feshchenko, D. V., Ryabtseva, N. O., et al. (2013). Efektivnist' znezarazhuvannya gnoyu riznikh vidiv sil's'kogospodars'kikh tvarin reagentami khimichnoï prirodi [Efficiency of decontamination with chemical agents of manure from different types of farm animals]. Bulletin of Poltava state agrarian academy, 2. pp. 92-94 [In Ukrainian].

5. Yarchuk, B. M., Verbits'kiy, P. I., Litvin, V.P., et al. (2002). Zagal'na epizootologiya [General epizootology]. White Church [In Ukrainian].

6. Zaklyuchitel'nyy otchet o nauchnoissledovatel'skoy rabote Odesskogo NII kurortologii $i$ meditsinskoy reabilitatsii: Izuchit' plastovye vody neftyanykh mestorozhdeniy na shesti uchastkakh Poltavskoy oblasti, opredelit' perspektivu lechebnogo primeneniya $i$ dat' lechebnuyu otsenku [Final report on the research work of the Ukrainian ScientificResearch Institute of Medical Rehabilitation and Balneology of the Ministry of Health of Ukraine (Odessa): To study reservoir water of oil fields in six areas of the Poltava region, to determine the possibility of therapeutic use and to give a therapeutic evaluation]. Odessa, 1991 [In Ukrainian].

7. Zorin, P. M. (1965). Bal'neologiya kozhnykh bol'nykh yodobromnoy vodoy Akhtyrskogo istochnika
13. Спосіб знезараження гною і отримання 3 нього більш якісного добрива : деклараційний пат. на корисну модель №12700/3У/18 від 18.05.2018 Україна : МПК Co5F3/0, АO1C3/00, F61L11/00 (20018.01). / Корчан Л. М., Корчан М. І., Писаренко П. В. № u 2018 02505; заявл. 12.03.2018.

14. Способ обеззараживания навоза : пат. РФ 2081864 / Ю. И. Житин, О.В.Алипатова. МПК:СО5F3/00 ; заявл. 03.04.1995 ; опубл. 20.06.1997.

[Balneology of skin patients with iodine-bromine water from the Okhtyrka source]. Journal of Dermatology and Venereology, 11, pp. 77-80 [In Russian].

8. Kotel'nikov, G. A. (1974). Diagnostika gel'mintozov zhivotnykh [Diagnostics of helminthiasis animals]. Moscow [In Russian].

9. Nabok, M.F. (1965). Lechenie zabolevaniy perifericheskoy nervnoy sistemy yodobromnymi vodami Borislava [Treatment of peripheral nervous system diseases with iodine-bromine waters of Boryslav]. Medical business, 8, pp. 121-122 [In Russian].

10. Galat, V.F., Berezovs'kiy, A. V., Soroka, N. M., Prus, M. P. (2009). Parazitolologiya ta innvaziyni khvorobi tvarin [Parasitology and noninvasive animal diseases]. Kyiv. pp. 21-22 [In Ukrainian].

11. Skryabin, K. I. (1973). Sovetskaya entsiklopediya [Soviet Encyclopedia]. Moscow: "Sovetskaya entsiklopediya". Vol.4. pp. 323-325 [In Russian].

12. Shkavro, Z. M., Omel'chenko, O. F., Medvedev, M. I. (2000). Sposib znezarazhennya gnoyu z podal'shim otrimannyam z n'ogo dobriva : pat. UA 29772 [A method of decontamination of manure with the following obtaining of fertilizers from it: pat. UA 29772] [In Russian].

13. Korchan, L. M., Korchan, M. I, Pisarenko, P. V. (2018). Sposib znezarazhennya gnoyu $i$ otrimannya z n'ogo bil'sh yakisnogo dobriva : declarative pat. for utility model \# 12700/3У/18 [A method for decontamination of manure and obtaining more qualitative fertilizers from it: declarative pat. for utility model \# 12700/3У/18]. MPK Co5F3/0, AO1C3/00, F61L11/00 (20018.01) [In Ukrainian].

14. Zhitin, Yu. I., Alipatova, O. V. (1997). Sposob obezzarazhivaniya navoza : pat. RF 2081864 [Method of disinfecting manure: pat. RF 2081864], MPK:CO5F3/00 [In Russian]. 


\section{СІЛЬСЬКЕ ГОСПОДАРСТВО. ТВАРИННИЦТВО}

Корчан Л. Н., Писаренко П. В., Корчан Н. И. Способ обеззараживания навоза и получения из него высококачественного удобрения

Цель статьи - создание более дешевого и эффективного способа обеззараживания навоза животных, обеспечения сокращения сроков обеззаражсивания навоза и улучшения качества полученного из него удобрения.

Методика исследования. В экспериментальных исследованиях нами были заложены исследовательские штабеля твердого подстилочного навоза крупного рогатого скота и коз, которые послойно обрабатывали в различных соотношениях к навозу йодобромной минерализованной пластовой водой (далее МПВ) Решетняковского месторождения. Контрольные штабеля навоза не обрабатывали МПВ. Через каждые 15 дней после закладки штабелей от них отбирались пробы навоза для изучения процесса его обеззараживания от бактериальных и инвазионных возбудителей.

Результаты исследования. Результаты проведенных микробиологических и гельминтологических исследований показали полное обеззараживание навоза от патогенной микрофлоры, яии и личинок гельминтов на 30-45 день в летний и 60-90 день в зимний период года в исследовательских штабелях навоза после послойной обработки его МПВ в объемных соотномениях $50 \mathrm{n} / \mathrm{M}^{3}$ навоза. В контрольных штабелях навоз оставался не обеззараженный в течение всего периода наблюдения. Было также доказано, что после обработки штабелей навоза МПВ отмечается существенное увеличение в нем органического вещества и питательныхх элементов: азота общего, азота аммиачного фосфора и калия.

Элементы научной новизны. Предложенный способ обеззаражсивания навоза и получения из него высококачественного удобрения включает добавление активного компонента для ускорения процесса биотермического обеззараживания навоза животных путем послойной обработки его природным минералом - йодобромной минерализованной пластовой водой.

Практическая значимость. Предложенный способ обеззараживания навоза и получения из него высококачественного удобрения является дешевым, эффективным, позволяет ускорить процесс биотермического обеззараживания навоза животных, существенно снизить загрязнение окружающей среды и может быть использован как средство повышения питательности органических удобрений. Значительно повышает практический интерес к МПВ и тот факт, что запасы этого природного минерала в Украине не ограничены.

Ключевые слова: навоз, биотермическое обеззаражсивания, удобрения, минерализованные пластовые воды.

Корчан Леонид Николаевич - кандидат ветеринарных наук, старший преподаватель кафедры паразитологии и ветеринарно-санитарной экспертизы, Полтавская государственная аграрная академия, ул. Сковороды, 1/3, г. Полтава, 36003, Украина, e-mail: korchan198@gmail.com, ORCID ID: 00000002-6064-5922.

Писаренко Павел Викторович - доктор сельскохозяйственных наук, профессор, академик инженерной Академии Украины, первый проректор, Полтавская государственная аграрная академія, ул. Сковороды, 1/3, г. Полтава, 36003, Украина, e-mail: pavlo.pysarenko@pdaa.edu.ua, ORCID ID: 00000002-4915-265X.

Корчан Николай Иванович - кандидат ветеринарных наук, доцент, доцент кафедры терапии имени П.И. Локеса, Полтавская государственная аграрная академия, ул. Сковороды, 1/3, г. Полтава, 36003, Украина, e-mail: korchan198@gmail.com.

Korchan L. M., Pysarenko P. V., Korchan M. I. The method of manure decontaminating and obtaining high-quality fertilizer from it

The purpose of the article is to create a cheaper and more effective method of decontaminating animal manure, to reduce the time of manure treatment, and to improve the quality of fertilizers obtained from it.

Research methods. In our experimental research the stacks of cattle and goat solid litter manure were set and then treated in layers with various ratios of iodine-bromine mineralized reservoir water (hereinafter referred as the MRW) of the Reshetniaky deposit. Control stacks of manure were not treated by MRW. Every 15 days after stacking, manure samples were taken to study the process of manure decontamination from bacterial and invasive pathogens. 
The research results. The results of the conducted microbiological and helminthological studies showed complete decontamination of manure from pathogenic micro-flora, eggs and larvae of helminthes on the 30$45^{\text {th }}$ day in the summer and 60-90 th day in the winter period of the year in experimental manure stacks after its layered treatment by MRW in volumetric ratios of 50 liters $/ \mathrm{m}^{3}$ of manure. In control stacks, manure remained not decontaminated throughout the observation period. It was also proved that after treating manure with $M R W$ there is a significant increase of organic matter and nutrient elements in it: total nitrogen, nitrogen of ammonium phosphorus and potassium.

The elements of scientific novelty. The offered method of decontaminating manure and obtaining high quality fertilizer from it involves the addition of an active component to accelerate the process of animal manure bio-thermal decontamination by layer treating it with natural mineral - iodine-bromine mineralized reservoir water.

Practical significance. The offered method of decontaminating manure receiving a high quality fertilizer from it is cheap, efficient, and enables to accelerate the process of bio-thermic decontamination of animal manure, significantly reduce environmental pollution and it can be used as a means of increasing the nutrient effectiveness of organic fertilizers. The fact that the reserves of this natural mineral in Ukraine are unlimited significantly increases the practical interest in MRW.

Key words: manure, bio-thermal decontamination, fertilizers, mineralized reservoir water.

Korchan Leonid Mykolaiovych - Candidate (PhD) of Veterinary Sciences, Senior Lecturer of the Department of Parasitology and Veterinary-Sanitary Expert Examination, Poltava State Agrarian Academy, 1/3, Skovorody st., Poltava, 36003, Ukraine, e-mail: korchan198@gmail.com, ORCID ID: 0000-0002-6064-5922.

Pysarenko Pavlo Viktorovych - Doctor of Agricultural Sciences, Professor, Academician of the Engineering Academy of Ukraine, First Vice-Rector, Poltava State Agrarian Academy, 1/3, Skovorody st., Poltava, 36003, Ukraine, e-mail: pavlo.pysarenko@pdaa.edu.ua, ORCID ID: 0000-0002-4915-265X.

Korchan Mykola Ivanovych - Candidate (PhD) of Veterinary Sciences, Associate Professor of the Department of Therapy named after P. I. Lokes, Poltava State Agrarian Academy, 1/3, Skovorody st., Poltava, 36003, Ukraine, e-mail: korchan198@gmail.com.

Стаття надійшла до редакції 13.02.2019 р.

Бібліографічний опис для цитування :

Корчан Л. М., Писаренко П. В., Корчан М. І. Спосіб знезараження гною і отримання з нього високоякісного добрива. Вісник ПДАА. 2019. № 1. С. 154-160.

DOI 10.31210/visnyk2019.01.17

(с) Корчан Леонід Миколайович, Писаренко Павло Вікторович, Корчан Микола Іванович, 2019 